\title{
ANALISIS UJI FUNGSI SISTEM ELEKTRODE IGNITOR UNTUK SUMBER ELEKTRON KATODE PLASMA
}

\section{ANALYSIS OF THE FUNCTIONAL TEST OF IGNITOR ELECTRODE SYSTEM FOR A PLASMA CATHODE ELECTRON SOURCE}

\author{
Lely Susita R.M., Sudjatmoko, Bambang Siswanto, Ihwanul Aziz \\ Pusat Sains dan Teknologi Akselerator, BATAN \\ Jl. Babarsari Kotak Pos 6101 Ykbb, Yogyakarta 55281 \\ e-mail: susita@batan.go.id
}

Diterima 03 Juni 2015, diterima dalam bentuk perbaikan 13 Juli 2015, disetujui 29 Juli 2015

\begin{abstract}
ABSTRAK
ANALISIS UJI FUNGSI SISTEM ELEKTRODE IGNITOR UNTUK SUMBER ELEKTRON KATODE PLASMA. Sistem elektrode sumber elektron katode plasma adalah suatu sistem yang berfungsi untuk menghasilkan plasma pulsa di dalam bejana generator plasma secara terkendali. Sistem elektrode terdiri dari sistem elektrode ignitor yang menginisiasi lucutan plasma dan sistem elektrode pembentuk plasma. Sistem elektrode ignitor yang dirancang tersusun dari bahan kuningan dan di depannya diberi penyambung dari bahan magnesium, bahan isolator terbuat dari teflon karena mempunyai nilai resitivitas elektrik yang tinggi $>10^{18} \Omega$ $\mathrm{cm})$, dan anode dibuat dari bahan SS 304 non magnetik. Bahan magnesium digunakan sebagai katode, karena magnesium mempunyai sifat fisis laju erosi paling rendah $(11,7 \mu \mathrm{g} / \mathrm{C})$ dan energi kohesif yang rendah sekitar 1,51 eV/atom. Dengan demikian semakin besar arus menuju katode akan semakin besar pula lucutan spot plasma yang dihasilkan. Hasil uji fungsi sistem elektrode ignitor diperoleh arus spot plasma 10,58 A dengan lebar pulsa $39 \mu \mathrm{s}$. Spesifikasi katode yang digunakan pada sistem elektrode ignitor berbentuk silinder dengan diameter $6 \mathrm{~mm}$ dan panjang $20 \mathrm{~mm}$. Untuk frekuensi pengulangan spot plasma $10 \mathrm{~Hz}$, katode akan tererosi dan berkurang sepanjang 17,64 $\mu \mathrm{m}$, sedangkan untuk katode tererosi membentuk kerucut, maka katode akan berkurang sepanjang 26,46 $\mu$ m untuk waktu pengujian sumber elektron katode plasma selama 5 jam. Bentuk erosi dari katode dipengaruhi oleh arus spot plasma, lebar pulsa serta kevakuman bejana plasma.
\end{abstract}

Kata kunci: sistem elektrode, material elektrode, sumber elektron katode plasma, magnesium

\begin{abstract}
ANALYSIS OF THE FUNCTIONAL TEST OF IGNITOR ELECTRODE SYSTEM FOR A PLASMA CATHODE ELECTRON SOURCE. Electrode system of the plasma cathode electron source is a system whose function to generate the plasma pulse in the plasma generator vessel in a controlled manner. Electrode system consists of the ignitor electrode system that initiates a plasma discharge and the plasma-forming electrode system. Ignitor electrode system is composed of brass and in the front of it given the coupling of magnesium, the insulating material made of Teflon because it has a high electrical resistivity value ( $\left.>10^{18} \Omega \mathrm{cm}\right)$, and the anode is made of nonmagnetic material SS 304. Magnesium is used as the cathode material, because the physical property of magnesium has the lowest erosion rate $(11.7 \mathrm{~g} / \mathrm{C})$ and a low cohesive energy of about $1.51 \mathrm{eV} /$ atom. Therefore, the greater currents flowing to a cathode it will produced greater plasma spot current. Ignitor electrode system function test obtained that the plasma spot current is $10.58 \mathrm{~A}$ with a pulse width of $39 \mu \mathrm{s}$. The specifications of cathode used in the ignitor electrode system is cylindrical form with diameter of $6 \mathrm{~mm}$ and length of $20 \mathrm{~mm}$. For repetition frequency of plasma spot of $10 \mathrm{~Hz}$, the cathode will be eroded and reduced along $17.64 \mu \mathrm{m}$, while for the cathode eroded to form a cone, then the cathode will be reduced along $26.46 \mu \mathrm{m}$ for the testing period plasma cathode electron sources for 5 hours. Erosion form of the cathode affected by a plasma spot current, pulse width and an vacuum degree of the plasma vessel.
\end{abstract}

Keywords: electrode systems, electrode materials, plasma cathode electron sources, magnesium 


\section{PENDAHULUAN}

Sesuai dengan tugas dan fungsi PSTA-BATAN, pada tahun-tahun sebelumnya telah dilakukan penelitian dan pengembangan sumber elektron berbasis katode plasma yang dapat dimanfaatkan untuk perangkat iradiator elektron pulsa (1). Komponen iradiator elektron pulsa berbasis SEKP (Sumber Elektron Katode Plasma) terdiri dari bejana iradiator elektron, bejana generator plasma dan tegangan pemercepat serta sistem pompa vakum. Bejana generator plasma yang juga disebut anode berongga mempunyai dua sistem elektrode pembentuk plasma di sisi kiri dan kanan, dengan grid yang dipasang di bawah dinding bejana yang juga berperan sebagai anode. Sistem elektrode yang dirancang untuk sumber elektron katode plasma adalah suatu sistem yang berfungsi untuk menghasilkan plasma pulsa di dalam bejana generator plasma secara terkendali.

Sistem SEKP terdiri dari dua sistem elektrode yaitu sistem elektrode ignitor dan sistem elektrode generator plasma, seperti ditunjukkan pada Gambar 1. Sistem elektrode ignitor yang menginisiasi lucutan terdiri dari dua buah elektrode ignitor yang dilengkapi dengan dua unit sistem catudaya lucutan ignitor (IDPS: Ignitor Discharge Power Supply). Sistem elektrode ignitor terdiri dari katode, anode dan isolator antara katode dan anode. Sistem elektrode generator plasma sebagai pembentuk plasma dalam bejana generator plasma dilengkapi dengan dua unit sistem catu daya lucutan busur (ADPS: Arc Discharge Power Supply) dan sistem deteksi arus lucutan dan kerapatan plasma. Sistem elektrode generator plasma terdiri dari katode yang juga sama dengan katode elektrode ignitor dan anode yang juga sebagai dinding bejana generator plasma.

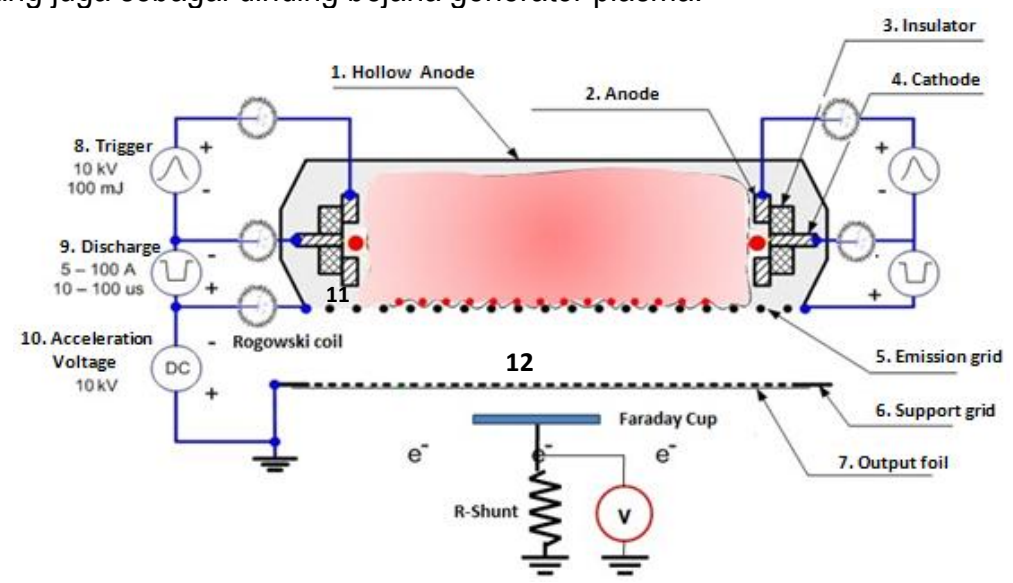

Gambar 1. Sistem Sumber Elektron Katode Plasma (2).

Seperti ditunjukkan pada Gambar 1, sistem elektrode ignitor sebagai pembentuk spot plasma mempunyai sistem catudaya lucutan ignitor IDPS (8) dan sistem catu daya lucutan busur plasma ADPS (9). Sistem IDPS (8) mempunyai spesifikasi tegangan $10 \mathrm{kV}$, dan energi $100 \mathrm{~mJ}$ mengalirkan arus melalui anode (2) dan melalui isolator (3) akan membentuk spot plasma (11) di permukaan katode (4) melalui proses lucutan permukaan pada bejana generator plasma (1) dengan tekanan gas sekitar $10^{-4}$ Torr. Kemudian spot plasma (11) yang terbentuk akan dihamburkan oleh sistem ADPS (9). Hamburan spot plasma yang dipercepat oleh sistem ADPS akan mengionkan gas dalam rongga bejana generator plasma terbentuk lucutan busur plasma (12) di sekitar daerah anode bejana generator plasma (1). Jika kedua sistem elektrode berjalan serempak maka keseluruhan ruang anode akan terbentuk lucutan busur plasma. Oleh tegangan pemercepat (10) elektron yang lolos melalui grid (5) akan dipercepat sampai mampu menembus jendela Ti/Be (7) yang selanjutnya dimanfaatkan untuk iradiasi bahan. Sistem iradiator elektron berbasis SEKP ini diharapkan dapat memberikan arus pulsa berkas elektron $50-100 \mathrm{~A}$ dan dalam luasan keluaran $15 \times 60 \mathrm{~cm}^{2}$. Iradiator elektron yang dapat menghasilkan keluaran berkas elektron dengan tampang-lintang luas dan arus berkas yang tinggi dapat diaplikasikan dalam teknologi radiasi, dalam modifikasi permukaan untuk struktur materi, dalam pemompaan media aktif gas laser dan dalam bidang-bidang lainnya (3-7).

Dalam makalah ini disajikan tentang deskripsi sistem SEKP, material elektrode, hasil konstruksi sistem elektrode ignitor, dan berdasarkan hasil konstruksi tersebut dilakukan uji fungsi dan dilanjutkan dengan analisis 
hasil uji fungsi sistem elektrode ignitor untuk menentukan arus spot plasma dan arus berkas elektron, serta penentuan massa tererosi material katode.

\section{METODOLOGI}

\section{Deskripsi Sistem Elektroda Ignitor}

Sistem elektrode yang dirancang adalah suatu sistem yang berfungsi untuk menghasilkan plasma pulsa di dalam bejana generator plasma secara terkendali. Sistem elektrode dirancang 2 buah yang ditempatkan di sisi kiri dan kanan bejana. Masing-masing sistem elektrode tersusun atas sistem elektrode ignitor yang menginisiasi lucutan dan sistem elektrode generator plasma. Sistem elektrode ignitor terdiri dari katode, anode dan isolator antara katode dan anode. Anode dan katode sistem elektrode ignitor terhubung dengan sumber daya ignitor. Dinding bejana generator plasma berfungsi sebagai anode, dan pada sisi bawah anode bejana generator plasma mempunyai lubang yang ditutup oleh grid. Katode dan anode bejana generator plasma dihubungkan dengan terminal sumber daya generator plasma.

\section{Material Sistem Elektrode}

\section{Material katode}

Spot plasma di permukaan katode mempunyai ukuran mikrometer dan berintensitas cukup tinggi. Parameter dari spot plasma adalah laju erosi ion (ion erosion rate), dapat ditentukan dengan cara mengukur arus ion maksimum pada kondisi lucutan busur. Dari hasil eksperimen yang dilakukan oleh para peneliti sebelumnya bahwa laju erosi ion merupakan karakteristik dari bahan katode dan tidak tergantung dari besarnya arus lucutan busur (8-10). Laju erosi ion umumnya lebih besar untuk unsur dengan energi kohesif rendah. Bahan-bahan yang mempunyai energi kohesif lebih besar memerlukan energi lebih besar untuk transformasi fase bahan katode padat menjadi plasma. Laju erosi ion dari material katode dapat ditentukan dengan cara mengukur arus ion total $l_{i}$, arus lucutan $l_{\text {arc, }}$ dan distribusi muatan (charge state distribution) $Q_{i}$, berdasarkan rumus

$$
\gamma_{i}=\frac{I_{i}}{I_{a n c}} \cdot \frac{M_{i}}{e \overline{Q_{i}}}=\alpha_{i} \cdot \frac{M_{i}}{e \overline{Q_{i}}},
$$

dimana normalisasi arus ion $\alpha_{i}=l_{i} / l_{\text {arc }}, M_{i}$ adalah massa atom dari material katode, e adalah muatan keunsuran (1,602 × 10-19 coulomb). Hasil penelitian laju erosi ion untuk berbagai bahan katode disajikan pada Tabel 1.

Tabel 1. Nilai normalisasi arus ion dan laju erosi ion pada arus lucutan $100 \mathrm{~A}$ (11).

\begin{tabular}{cccc}
\hline Material Katode & $\begin{array}{c}\text { Energi Kohesif } \\
(\mathrm{eV} / \text { atom })\end{array}$ & $\alpha_{i}(\%)$ & $\gamma_{1}(\mu \mathrm{g} / \mathrm{C})$ \\
\hline $\mathrm{C}$ & 7,37 & 11,3 & 13,5 \\
\hline $\mathrm{Mg}$ & 1,51 & 8,3 & 11,7 \\
\hline $\mathrm{Ag}$ & 2,95 & 6,0 & 27,8 \\
\hline $\mathrm{Al}$ & 3,39 & 8,3 & 14 \\
\hline $\mathrm{Cu}$ & 3,49 & 6,8 & 19,3 \\
\hline $\mathrm{Cd}$ & 1,16 & 5,8 & 43,9 \\
\hline $\mathrm{Ti}$ & 4,85 & 6,8 & 15,2 \\
\hline $\mathrm{Fe}$ & 4,28 & 6,0 & 16,9 \\
\hline $\mathrm{Ni}$ & 4,44 & 4,8 & 14,5 \\
\hline $\mathrm{Co}$ & 4,39 & 5,0 & 15,3 \\
\hline
\end{tabular}


Dari data pada Tabel 1 dapat diketahui bahwa material katode untuk sistem elektrode ignitor paling baik menggunakan material $\mathrm{Mg}$ karena mempunyai laju erosi ion $\gamma_{i}$ paling rendah $(11,7 \mu \mathrm{g} / \mathrm{C})$ sehingga tidak mudah rusak (tererosi), serta mempunyai energi kohesif yang rendah (pada energi 1,51 eV telah terbentuk plasma). Semakin besar arus menuju katode maka semakin besar spot plasma yang dihasilkan sehingga semakin besar pula partikel magnesium tererosi, oleh karena itu sistem elektrode ignitor yang dirancang menggunakan material Mg.

\section{Material anode}

Kriteria dari bahan anode pada sistem elektrode adalah:

1. Tahan terhadap suhu tinggi

2. Tahan terhadap korosi

3. Sifat daktilitas (keuletan) tinggi, sehingga dapat dengan mudah dibentuk.

Material anode pada sistem elektrode ignitor adalah stainless steel (baja tahan karat) austenit yang sering digunakan dalam aplikasi yang memerlukan material bukan magnet. Stainless Steel (SS) adalah paduan besi dengan minimal $12 \%$ kromium. Komposisi ini membentuk protective layer (lapisan pelindung anti korosi) yang merupakan hasil oksidasi oksigen terhadap krom yang terjadi secara spontan. Meskipun seluruh kategori SS didasarkan pada kandungan krom ( $\mathrm{Cr}$ ), namun unsur paduan lainnya ditambahkan untuk memperbaiki sifat-sifat SS sesuai aplikasinya.

\section{Sifat fisik stainless steel}

Dalam sistem SEKP diperlukan beberapa komponen dengan beberapa jenis bahan stainless steel yang memenuhi sifat fisik tertentu. Dalam Tabel 2 berikut disajikan sifat-sifat fisik beberapa jenis stainless steel.

\section{Sifat mekanik stainless steel}

SS dapat dibagi menjadi empat kelompok dengan sifat yang sama dalam setiap kelompok: martensit dan feritik-martensit, feritik, austenitik-feritik dan austenitik. Baja martensit mempunyai kekuatan tarik (tensile strengths) tinggi tetapi sifat daktilitasnya (keuletan) rendah, sedangkan kekuatan baja austenitik rendah dan daktilitasnya sangat baik. Baja feritik-austenitik dan feritik mempunyai sifat mekanik di antara baja martensit dan austenitik.

Tabel 2. Sifat fisik untuk berbagai tipe stainless steel (12).

\begin{tabular}{lcccc}
\hline \multicolumn{1}{c}{ Sifat Fisik } & \multicolumn{4}{c}{ Tipe Stainless Steel } \\
\cline { 2 - 5 } & Martensit & Ferit & Austenit & Ferit-Austenit \\
\hline Densitas $\left(\mathrm{g} / \mathrm{cm}^{3}\right)$ & $7,6-7,7$ & $7,6-7,8$ & $7,9-8,2$ & 0,8 \\
\hline Modulus Young $(\mathrm{MPa})$ & 220 & 220 & 195 & 200 \\
\hline Ekspansi Termal $\left(\times 10^{-6} /{ }^{\circ} \mathrm{C}\right) 200-600^{\circ} \mathrm{C}$ & $12-13$ & $12-13$ & $17-19$ & 13 \\
\hline Konduktivitas Termal $\left(\mathrm{W} / \mathrm{m}^{\circ} \mathrm{C}\right) 20^{\circ} \mathrm{C}$ & $22-24$ & $20-23$ & $12-15$ & 20 \\
\hline Kapasitas Panas $\left(\mathrm{J} / \mathrm{kg}^{\circ} \mathrm{C}\right) 20^{\circ} \mathrm{C}$ & 460 & 460 & 440 & 400 \\
\hline Resistivitas $(\mathrm{n} \Omega \mathrm{m}) 20^{\circ} \mathrm{C}$ & 600 & $600-750$ & 850 & $700-850$ \\
\hline Sifat Magnet & Magnet & Magnet & Bukan & Magnet \\
\hline
\end{tabular}

Berdasarkan sifat-sifat bahan SS tersebut di atas, komponen anode pada sistem elektrode ignitor dan anode pada sistem elektrode generator plasma yang merupakan dinding bejana plasma dibuat dari material SS 304 (kelompok baja tahan karat austenitik), karena SS 304 mempunyai sifat daktilitas (keuletan) tinggi sehingga dapat dengan mudah dibentuk, sifat mampu las yang baik (weldability) dan non magnetik. 


\section{Material isolator}

Fungsi yang paling penting dari material isolator adalah untuk mengisolasi/memisahkan bagian bagian yang bertegangan satu sama lain dan terhadap bumi (ground). Namun demikian selain berfungsi sebagai isolator, material ini harus mampu menahan beban mekanis, mampu menahan beban panas maupun tahan terhadap korosi. Beban-beban tersebut seringkali terjadi secara simultan, sehingga efek bersama dari berbagai parameter tersebut harus diketahui. Dalam sumber elektron katode plasma, isolator digunakan untuk sekat antara katode dan anode dan akan menerima beban tekan, radiasi, lingkungan reaktif (plasma), beroperasi pada temperatur plasma yang cukup tinggi dan dioperasikan pada tegangan tinggi pula $(150 \mathrm{kV})$. Berdasar pada pertimbangan tersebut maka sebagai isolator dipilihlah Teflon (PTFE) atau Poliamide (PA6) yang sifat-sifatnya disajikan pada Tabel 3.

Tabel 3. Sifat-sifat (mekanik, termal dan elektrik) teflon dan matetrial sejenisnya (13).

\begin{tabular}{|c|c|c|c|c|c|c|c|c|c|}
\hline No & Description & Unit & $\begin{array}{l}\text { PTFE } \\
\text { (Teflon) }\end{array}$ & PE & PC & POM & PP & PVC & PA6 \\
\hline \multicolumn{10}{|c|}{ Mechanical Properties (Sifat Mekanik) } \\
\hline 1 & Density & $\mathrm{g} / \mathrm{cm}^{3}$ & 2,18 & 0,97 & 1,2 & 1,41 & 1 & 1,4 & 1,7 \\
\hline 2 & Tensile Strength & $\mathrm{MPa}$ & 33,4 & 22,1 & 40 & 60 & 33 & 55 & 76 \\
\hline 3 & Elongation of Break & $\%$ & 500 & 400 & 110 & 35 & 148 & 33 & 30 \\
\hline 4 & Ball Indentation Hardness & $\mathrm{N} / \mathrm{mm}^{2}$ & 30 & 38 & 80 & 140 & 75 & 75 & 165 \\
\hline 5 & Modulus of Elasticity & $\mathrm{N} / \mathrm{mm}^{2}$ & 700 & 700 & 2300 & 3200 & 1450 & 3000 & 3100 \\
\hline \multicolumn{10}{|c|}{ Thermal Properties } \\
\hline 1 & $\begin{array}{l}\text { Max Continuous } \\
\text { Operating Temperature }\end{array}$ & ${ }^{\circ} \mathrm{C}$ & 260 & 80 & 125 & 110 & 90 & 60 & 100 \\
\hline 2 & $\begin{array}{l}\text { Thermal Conductivity@ } \\
23^{\circ} \mathrm{C}\end{array}$ & $\mathrm{W} / \mathrm{m}^{*} \mathrm{~K}$ & 0,21 & 0,4 & 0,19 & 0,31 & 0,22 & 0,14 & 0,23 \\
\hline
\end{tabular}

Electrical Properties

\begin{tabular}{llcccccccc}
\hline 1 & Volume Resistance & Ohm.cm & $>10^{18}$ & $>10^{15}$ & $>10^{17}$ & $>10^{15}$ & $>10^{16}$ & $>10^{15}$ & $>10^{15}$ \\
\hline 2 & Surface Resistance & $\mathrm{Ohm}$ & $>10^{14}$ & $>10^{14}$ & $>10^{15}$ & $>10^{13}$ & $>10^{13}$ & $>10^{13}$ & $>10^{13}$ \\
\hline 3 & Dielectric Strength & $\mathrm{kV} / \mathrm{mm}$ & 11 & 45 & 27 & 55 & 127 & 20 & 26,4 \\
\hline
\end{tabular}

Material isolator antara katode ignitor dan anode ignitor terbuat dari teflon, karena mempunyai nilai resitivitas elektrik yang tinggi (>1018 $\Omega . \mathrm{cm}$ ), sedangkan material isolator pada sistem elektrode generator plasma dibuat dari poliamide (PA6), karena konstruksi isolator antara katode ignitor dan anode generator plasma memerlukan sifat mekanik (kekerasan) yang tinggi.

\section{Sistem Elektrode Ignitor}

Untuk bejana generator plasma dengan tekanan sekitar $10^{-4}$ Torr, berdasar aturan Paschen, tegangan dadal antara katode dan anode sangat besar (sekitar ratusan $\mathrm{kV}$ untuk jarak elektrode beberapa $\mathrm{cm}$ ), oleh karena itu sistem elektrode ignitor mempunyai susunan seperti ditunjukkan pada Gambar 2. Susunan elektrode ignitor yang utama terdiri dari katode dari bahan kuningan (1), dan di depannya diberi penyambung dari bahan magnesium (2), kemudian isolator silinder teflon setebal $1 \mathrm{~mm}$ (3) dan sebagai anode dari SS 304 (4). Bahan magnesium digunakan sebagai katode, karena magnesium mempunyai sifat fisis laju erosi $\gamma$ sebesar $11,7 \mu \mathrm{g} / \mathrm{C}$ ( $\mathrm{C}$ coulomb) dan tenaga kohesif rendah sekitar $1.51 \mathrm{eV} /$ atom ${ }^{(8,11)}$. Dengan demikian semakin besar arus menuju katode akan semakin besar pula spot plasma yang dihasilkan. 


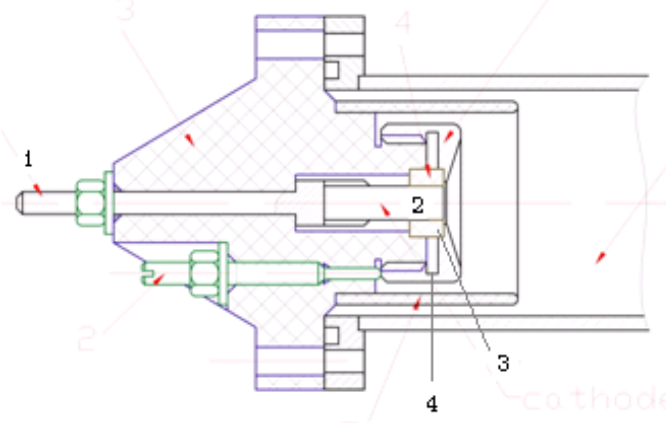

Gambar 2. Susunan sistem elektrode ignitor.

Dalam lucutan permukaan ini silinder teflon (3) yang berada di antara katode (2) dan anode (4) berperilaku sebagai kapasitor yang menerima muatan dari sumber tegangan ignitor melalui anode baja tahan karat. Dalam selang waktu tertentu kapasitor teflon akan termuati penuh, dan oleh karena kapasitor teflon tersebut bertegangan $10 \mathrm{kV}$ dan menempel erat dengan katode magnesium maka ia akan melimpahkan seluruh energinya kepada katode magnesium dan oleh tegangan muatan yang ada di kapasitor teflon yang sangat besar terjadilah lucutan spot di permukaan katode. Untuk menimbulkan spot plasma pada permukaan katode ignitor, dibutuhkan tegangan sekitar 9 - $10 \mathrm{kV}$ pulsa dengan energi sekitar $100 \mathrm{~mJ}$.

\section{Uji Fungsi Sistem Elektrode Ignitor}

Uji fungsi sistem elektrode ignitor dilakukan menggunakan 1 unit IDPS dengan 2 trafo flyback seperti yang ditunjukkan pada Gambar 3. Sistem sumber daya ignitor mempunyai spesifikasi tegangan $10 \mathrm{kV}$, dan energi 100 $\mathrm{mJ}$ mengalirkan tegangan melalui anode dan isolator akan membentuk spot plasma di permukaan katode.

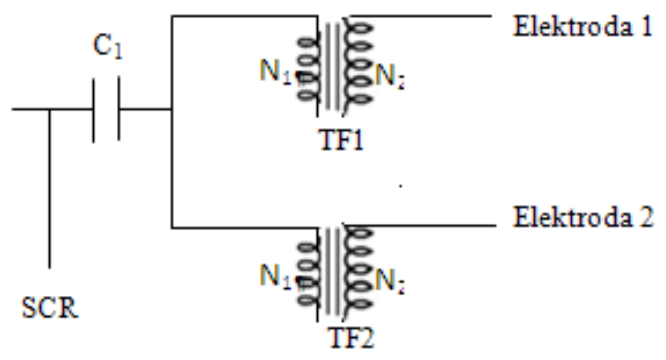

Gambar 3. Rangkaian sistem catudaya lucutan ignitor (IDPS).

Pengukuran tegangan keluaran sumber daya ignitor pembentuk spot plasma menggunakan probe pembagi tegangan, dimana hasil pengukuran tegangan diturunkan 1000 kali yaitu dengan menggunakan resistor pembagi tegangan $50 \mathrm{M} \Omega / 50 \mathrm{k} \Omega$, dan arus spot plasma dapat ditentukan dengan menggunakan koil Rogowski. Koil Rogowski mempunyai prinsip kerja mendeteksi medan magnet di dalam ruang di sekitar konduktor yang dialiri arus. Tegangan keluaran koil dirumuskan sebagai laju perubahan fluks magnet (14),

$$
V_{\text {keluaran koil }}=\frac{d \Phi}{d t}=\frac{\mu_{0} n A}{2 \pi r} \frac{d I}{d t}
$$

Dengan demikian dapat diketahui bahwa tegangan keluaran koil Rogowski tergantung pada besarnya perubahan arus per satuan waktu, jumlah lilitan, luas permukaan koil dan jarak dari sumbu arus. Terlihat pada persamaan (2) bahwa tegangan keluaran koil sebanding dengan perubahan arus $\mathrm{d} / \mathrm{d} t$, sehingga untuk menentukan besarnya arus II $(t)$ maka tegangan keluaran koil harus diintegralkan. Dalam eksperimen, tegangan keluaran koil dikopel dengan rangkaian integrator RC, sehingga besarnya arus dapat ditentukan menurut persamaan 


$$
I(t)=\frac{2 \pi r R C}{\mu n A} V(t)
$$

dimana $I(t)$ adalah arus spot plasma, $R$ adalah resistansi integrator, $C$ adalah kapasitan integrator, dan $V(t)$ adalah tegangan terukur.

Parameter dari spot plasma adalah laju erosi ion (ion erosion rate), sedangkan laju erosi ion merupakan karakteristik dari bahan katode. Semakin besar arus menuju katode maka semakin besar spot plasma yang dihasilkan sehingga semakin besar pula material katode yang tererosi.
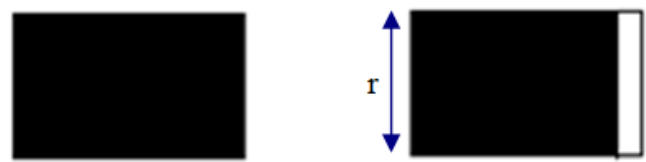

Gambar 4. Material katode berkurang sepanjang $\mathrm{d} X$.

Apabila selama sekian kali lucutan dari IDPS yang membentuk spot, material katode berkurang sepanjang $\mathrm{d} X$ (Gambar 4), maka massa material yang berkurang sepanjang $\mathrm{d} X$, mengikuti persamaan

$$
M_{\text {erosi }}=\rho \pi r^{2} d X
$$

dengan $\rho$ adalah rapat massa material katode, $r$ jari-jari katode dan $\mathrm{d} X$ adalah pengurangan bahan. Massa tererosi ini sama dengan jumlah sekian kali lucutan spot IDPS dikalikan dengan massa tererosi setiap lucutan IDPS, atau dirumuskan

$$
\begin{gathered}
M_{\text {erosi }}=N m_{\text {erosi setiap lucutan }} \\
m_{\text {erosi setiap lucutan }}=\gamma I \tau
\end{gathered}
$$

Untuk material katode yang tererosi menjadi bentuk kerucut, massa material yang tererosi mengikuti persamaan

$$
M_{\text {exasi }}=V \rho
$$

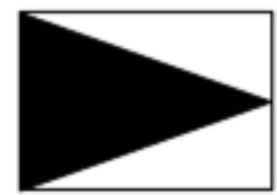

Gambar 5. Material katode tererosi menjadi bentuk kerucut.

$$
\begin{aligned}
& V=V^{y}-V^{u} \\
& V=\pi r^{2} t-\frac{1}{3} \pi r^{2} t \\
& V=\frac{2}{3} \pi r^{2} t=\frac{\pi t}{3}\left(2 r^{2}\right) \\
& M_{\text {exasi }}=V \rho=\frac{\rho \pi t}{3}\left(2 r^{2}\right)
\end{aligned}
$$


dengan $\rho$ adalah rapat massa material katode, $r$ adalah jari-jari alas kerucutjari jari katode dan $t$ adalah panjang kerucut. Dari hasil uji fungsi modul sistem elektrode dan dengan menggunakan persamaan (4) dan (8) dapat dilakukan perhitungan besarnya massa material katode yang tererosi.

\section{HASIL DAN PEMBAHASAN}

Untuk uji fungsi sistem elektrode ignitor digunakan komponen sistem elektrode ignitor yang telah selesai dikonstruksi. Sistem elektrode ignitor tersebut yang terdiri dari katode, anode dan isolator yang dirangkai menjadi modul sistem elektrode ignitor seperti ditampilkan pada Gambar 6. Uji fungsi dilakukan dengan menggunakan sistem elektrode ignitor yang dilengkapi dengan sistem IDPS, sistem elektrode generator plasma, sistem vakum dan sistem deteksi yang dirangkai menjadi satu unit SEKP (seperti Gambar 1). Bejana generator plasma yang berada di dalam bejana uji SEKP, terbuat dari bahan stainless-steel bentuk silinder dengan diameter $4,0 \mathrm{~cm}$ dan panjang $48,75 \mathrm{~cm}$. Pada sisi kiri dan kanan bejana generator plasma diletakkan sistem elektrode ignitor, yang terdiri dari katode dengan spesifikasi: material katode terbuat dari Mg berbentuk batang diameter $6 \mathrm{~mm}$ dan panjang $20 \mathrm{~mm}$; sebuah anode dengan material anode SS 304 non magnetik berbentuk silinder dengan diameter luar $28 \mathrm{~mm}$, diameter dalam $7,5 \mathrm{~mm}$ dan tebal $14 \mathrm{~mm}$; material isolator antara katode dan anode terbuat dari teflon berbentuk silinder, diameter dalam $6 \mathrm{~mm}$, diameter luar $12,5 \mathrm{~mm}$ dan panjang $6 \mathrm{~mm}$, seperti ditunjukkan pada Gambar 6.

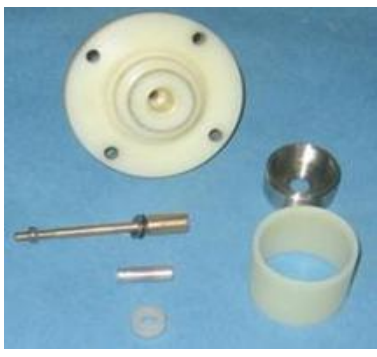

(a)

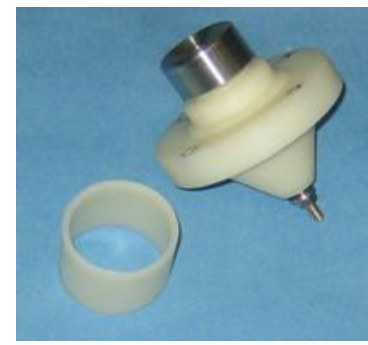

(b)

Gambar 6. (a). Komponen sistem elektrode ignitor, dan (b). Komponen sistem elektrode ignitor yang telah dirangkai menjadi satu modul sistem elektrode ignitor.

Penentuan arus spot plasma dan arus lucutan busur plasma dalam uji fungsi sistem elektrode ignitor dan elektrode generator plasma digunakan teknik koil Rogowski. Berdasarkan uji fungsi sistem elektrode ignitor dan elektrode generator plasma tersebut diperoleh pulsa arus spot plasma dan pulsa arus lucutan busur plasma seperti ditampilkan pada Gambar 7. Untuk menghitung besarnya arus spot plasma digunakan persamaan (3) di atas, dimana $R=100 \Omega$ adalah resistansi integrator, $C=0,33 \mu \mathrm{F}$ adalah kapasitan integrator. Koil Rogowski yang dibuat menggunakan core ferrite dengan nilai permeabilitas bahan $\mu$ sekitar $1017,36 \mathrm{H} / \mathrm{m}$, jumlah lilitan $n=76$, luas permukaan koil $A=45 \times 10^{-6} \mathrm{~m}^{2}$ dan jarak dari pusat koil Rogowski $r=9,25 \times 10^{-3} \mathrm{~m}$. Berdasarkan persamaan (3) tersebut diperoleh besarnya arus spot plasma $I_{s}=10,58$ ampere dengan lebar pulsa $\tau=39 \mu \mathrm{s}$.

Gambar 8 menampilkan hasil uji fungsi sistem SEKP yang telah menghasilkan berkas elektron yang dideteksi menggunakan teknik mangkuk Faraday dan teknik koil Rogowski, dimana tegangan ekstraksi $V_{\text {eks }}=3 \mathrm{kV}$ dipasang antara grid dan permukaan bejana uji SEKP. Berdasarkan Gambar 8 tersebut besarnya tegangan keluaran dari pulsa arus berkas elektron menggunakan koil Rogowski $V_{e}=2,88$ volt dengan lebar pulsa $\tau=136,0 \mu \mathrm{s}$. Dengan menggunakan persamaan (3) tersebut di atas dapat ditentukan besarnya arus berkas elektron $l_{\mathrm{e}}=34,3$ ampere untuk arus spot plasma 10,58 ampere. Berdasarkan hasil uji fungsi sistem elektrode ignitor tersebut dapat dilakukan analisis besarnya massa dan partikel material katode ignitor yang tererosi untuk menentukan umur katode akibat hilangnya bahan di permukaan katode setelah terbentuk spot plasma. 


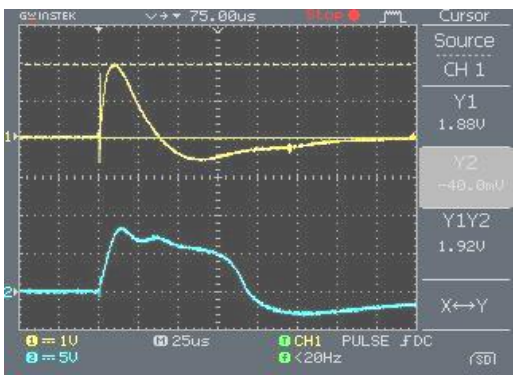

Gambar 7. Pulsa spot plasma dengan tegangan terukur $V_{s}=1,92$ volt dan lebar pulsa $\tau=39,0 \mu$ s. (gambar atas) dan pulsa lucutan busur plasma dengan tegangan terukur $V_{b}=6,0$ volt dan lebar pulsa $\tau=123,78 \mu \mathrm{s}$. (gambar bawah).

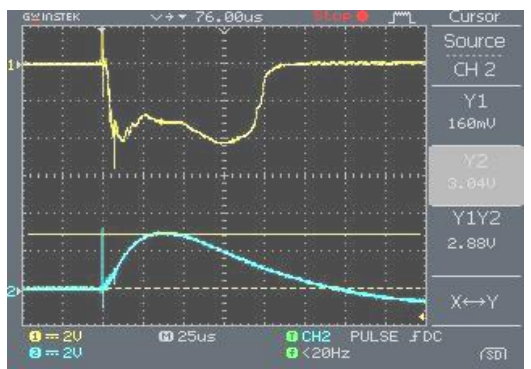

Gambar 8. Pulsa berkas elektron yang terdeteksi menggunakan mangkuk Faraday (gambar atas) dan menggunakan koil Rogowski dengan tegangan $V_{\mathrm{e}}=2,88$ volt dan lebar pulsa $\tau=136,0 \mu \mathrm{s}$. (gambar bawah).

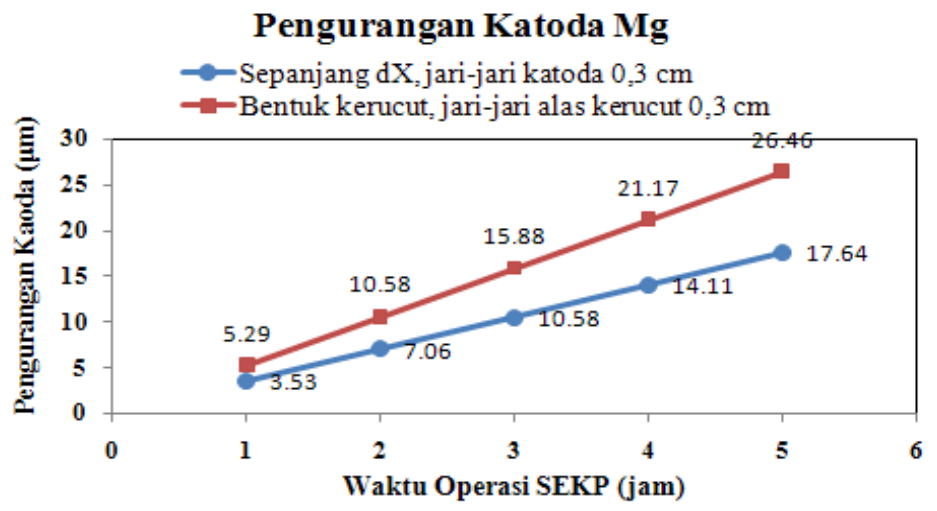

Gambar 9. Pengurangan katode Mg.

Dari hasil uji fungsi sistem elektrode ignitor dengan menggunakan koil Rogowski diperoleh arus dan lebar pulsa spot plasma, dan dengan menggunakan persamaan (4) dan (7) dapat dilakukan perhitungan pengurangan katode tererosi sepanjang $\mathrm{d} X$ dan katode yang tererosi menjadi bentuk kerucut. Hasil perhitungan ini ditampilkan pada Gambar 9, dan dari data-data tersebut dapat diketahui umur katode akibat hilangnya bahan di permukaan katode setelah terbentuk spot plasma.

Katode yang digunakan pada sistem elektrode ignitor mempunyai spesifikasi: material katode dari magnesium berbentuk batang berdiameter $6 \mathrm{~mm}$ dan panjang $20 \mathrm{~mm}$. Untuk frekuensi pengulangan spot plasma $10 \mathrm{~Hz}$, material katode akan tererosi dan berkurang sepanjang 17,64 $\mu$ m untuk waktu pengujian sumber elektron katode plasma selama 5 jam atau 0,85 mm selama waktu pengujian 1 tahun, sedangkan untuk material katode tererosi membentuk kerucut, maka material katode akan berkurang sepanjang $26,46 \mu \mathrm{m}$ dengan waku pengujian 5 jam atau 1,27 mm untuk waktu pengujian 1 tahun. Bentuk erosi dari material katode dipengaruhi oleh arus spot plasma, lebar pulsa serta kevakuman bejana plasma. 


\section{KESIMPULAN}

Berdasarkan hasil penelitian dan pembahasan seperti yang telah diuraikan di atas dapat diambil kesimpulan sebagai berikut. Hasil uji fungsi dan kinerja sumber elektron berbasis katode plasma diperoleh arus berkas elektron 34,3 A dengan lebar pulsa $136 \mu$ s, untuk arus spot plasma 10,58 A dengan lebar pulsa $39 \mu \mathrm{s}$. Katode yang digunakan pada sistem elektrode ignitor mempunyai spesifikasi: material katode dari magnesium berbentuk silinder diameter $6 \mathrm{~mm}$ dan panjang $20 \mathrm{~mm}$. Untuk frekuensi pengulangan spot plasma $10 \mathrm{~Hz}$, material katode akan tererosi dan berkurang sepanjang 17,64 $\mu \mathrm{m}$, sedangkan untuk material katode tererosi membentuk kerucut, maka material katode akan berkurang sepanjang 26,46 $\mu \mathrm{m}$ untuk waktu pengujian sumber elektron katode plasma selama 5 jam.

\section{UCAPAN TERIMA KASIH}

Kegiatan Penelitian ini dibiayai oleh PSTA melalui DIPA Tahun 2014. Pada kesempatan ini penulis mengucapkan terima kasih kepada Bapak Kepala PSTA dan juga seluruh peneliti dan pembantu peneliti kegiatan rancangbangun sumber elektron katode plasma; khususnya kepada Bapak Widdi Usada, Bapak Heri Sudarmanto, dan Bapak Untung Margono, atas bantuan baik teori maupun teknis sehingga pelaksanaan kegiatan uji fungsi sistem elektrode ignitor dapat terlaksana dengan baik, dan penulisan karya tulis ilmiah ini dapat terwujud.

\section{DAFTAR PUSTAKA}

1. SUDJATMOKO, Dokumen Rancangan Bejana Iradiator, Sistem Vakum Tinggi, Sistem Ekstraksi, Sistem Emisi dan Sistem Deteksi Berkas Elektron Pulsa, Pustek Akselerator dan PSTA - BATAN, Yogyakarta (2015) $1-18$

2. EFIM OKS, Lecture 8 : Introduction of Plasma Cathode Electron Source, presented in BATAN Accelerator School, Yogyakarta, Indonesia, December 5th -9th, (2011) 1 - 17

3. J.Z. GLEIZER, V. VEKSELMAN, S. YATOM, J. FELSTEINER, and Y.E. KRASIK, Radiation Effects \& Defects in Solids, Volume 166, Issue 6, (2011) 389 - 398

4. Y.E. KRASIK, D. YARMOLICH, J.Z. GLEIZER, V. VEKSELMAN, Y. HADAS, V.T. GUROVICH, and J. FELSTEINER, Physics of Plasmas 16, 057103 (2009) 057103-1 - 057103-11

5. J.Z. GLEIZER, Y. HADAS, V.T. GUROVICH, J. FELSTEINER, and Y.E. KRASIK, Journal of Applied Physics 103, 043302 (2008) 043302-1 - 043302-11

6. M.S. VOROB'EV, V.V. DENISOV, N.N. SHUGUROV, V.V. YAKOVLEV, K. UEMURA, and P. RAHARJO, Radiation Processing of Nayural Latex Using a Wide-Aperture Electron Accelerator with a Plasma Emitter, High Energy Chemistry, Volume 49, Issue 3 (2015) 143 - 145

7. R. PURWADI, Application of Large Area Plasma Cathode Electron Beam for Natural Rubber Vulcanization, ITAC Ltd., 8-2 Kamisuwa Tsubame City Niigata 959-0181 Niigata, Japan (2010) 497 - 501

8. A. ANDERS, E.M. OKS, G. YU YUSKHOV, K.P. SAVKIN, Y. BROWN, and A.G. NIKOLAEV, Determination of the Specific lon Erosion of the Vacuum Arc Cathode by Measuring the Total lon Current from the Discharge Plasma, Technical Physics, Vol. 51, No. 10, (2006) 1311 - 1315

9. E.M. OKS, K.P. SAVKIN, G.YU.YUSHKOV, and A.G. NIKOLAEV, Measurement of Total lon Current from Vacuum Arc Plasma Sources, Review of Scientific Instruments, 77, 03B504 (2006) 03B504-1 - 03B504-15

10. A. ANDERS, E.M. OKS, G. YU. YUSHKOV, K.P. SAVKIN, I.G. BROWN, A.G. NIKOLAEV, Measurements of The Total Ion Flux from Vacuum Arc Cathode Spots, IEEE Transactions on Plasma Science, Volume 33, Issue 5, (2005) 1532 - 1536

11. E.M.OKS, I. BROWN, Emerging Applications of Vacuum-Arc-Produced Plasma, Ion and Electron Beams, NATO Science Series II, Volume 88, Springer Science \& Business Media, (2012) 1 - 14

12. B. LEFFLER, Stainless Steels and Their Properties, http://www.outokumpu.com/files/group/hr/ documents/stainless20.pdf, diakses Juni (2014) 
13. M.M. MITTAL, Properties of PTFE and Some Other Insulating Materials, (2002), www.druflon.com/ ptfeprop.htm, diakses Pebruari (2012)

14. Y. BING, W. YUTIAN, L. HUI, W. HUIXIN, C. YIQIANG, Sensors \& Transducers, Vol. 165, Issue 2, February (2014) 35 - 39 